\title{
SINTESIS NANOPARTIKEL PERAK (NPAg) DENGAN BIOREDUKTOR EKSTRAK BIJI JARAK PAGAR DAN KAJIAN AKTIVITAS ANTIBAKTERINYA
}

\author{
[Synthesis of Silver Nanoparticle (NPAg) using Seed Aqueous Extract of \\ Jatropha Curcas L and Their Anti-Bacterial Activity Assessment]
}

\author{
Ara Nugrahayu Nalawati ${ }^{1) \star}$, Nugraha Edhi Suyatma ${ }^{2)}$, dan Danu Indra Wardhana ${ }^{1)}$ \\ 1) Program Studi Teknologi Industri Pertanian, Fakultas Pertanian, Universitas Muhammadiyah Jember, Jember \\ 2) Departemen IImu dan Teknologi Pangan, Fakultas Teknologi Pertanian, IPB University, Bogor
}

Diterima 18 Juni 2020 / Disetujui 22 Oktober 2021

\begin{abstract}
The redox analysis as indicated by a change in color from yellow to reddish-brown was measured at the optimum wavelength of $405 \mathrm{~nm}$ with the highest redox result of $480 \mathrm{~nm}$ obtained in the NPAg-S sample. The optimal absorption wavelength changes according to the characteristics of the NPAg produced, but is generally in the range of $400-500 \mathrm{~nm}$. Analysis of the active groups with the FTIR instrument showed active groups $(\mathrm{OH}, \mathrm{CH}$ aldehyde, vibrations of $\mathrm{CN}$ bonds in the amine group, amide I groups from proteins, and CO double bonds in the 4000-1500 $\mathrm{cm}^{-1}$ ) zone. Additionally, in the identification zone 1500-600 $\mathrm{cm}^{-1}$ the formation of $\mathrm{CN}$ bond vibrations and the presence of an amide I group from the protein was found. Photographs at 10.000 and 15.000x magnification showed that the morphology of the distribution of NPAg in the jatropha seed extract solution was polydisperse and in the form of fibrous balls with non-uniform particles and tended to agglomerate. The distribution and size of the particles measured using the Particle Size Analyzer (PSA) instrument showed that the particle size ranged from 33-116 nm. NPAg-S samples at two concentrations (1 and 2\%) showed inhibitory activity for all types of Gram positive and Gram negative bacteria. Analysis of the particle size distribution using PSA showed that the particle size of the NPAg-S sample was $33.8 \mathrm{~nm}$, which was smaller than the NPAg-K sample of $44.8 \mathrm{~nm}$. Antibacterial activity is strongly influenced by the particle size of a sample. Small size silver nanoparticles have a large surface area to interact with bacteria as compared to large silver nanoparticles, thus they can provide a greater antibacterial effect.
\end{abstract}

Keywords: antibacterial activity, Jatropha curcas L., particle size analysis, silver nanoparticles

\begin{abstract}
ABSTRAK
Analisis redoks yang ditandai perubahan warna kuning menjadi cokelat kemerahan diukur pada panjang gelombang optimum $405 \mathrm{~nm}$ dengan hasil redoks tertinggi $480 \mathrm{~nm}$ diperoleh pada sampel NPAgS. Panjang gelombang serapan optimal berubah sesuai dengan karakteristik NPAg yang dihasilkan, akan tetapi pada umumnya pada rentang 400-500 nm. Analisis gugus aktif dengan instrumen FTIR dengan hasil gugus aktif $(\mathrm{O}-\mathrm{H}, \mathrm{C}-\mathrm{H}$ aldehid, vibrasi ikatan $\mathrm{C}-\mathrm{N}$ pada kelompok gugus amina, gugus amida I dari protein, serta ikatan rangkap dua C-O pada zona 4000-1500 $\mathrm{cm}^{-1}$ ) dan pada zona identifikasi $1500-600$ $\mathrm{cm}^{-1}$ ditemukan terbentuknya vibrasi ikatan $\mathrm{C}-\mathrm{N}$ dan adanya gugus amida I dari protein. Foto pada perbesaran 10.000 dan 15.000x menunjukkan hasil bahwa morfologi sebaran NPAg dalam larutan ekstrak biji jarak bersifat polidispersi dan berbentuk bola berserabut dengan partikel yang tidak seragam serta cenderung beraglomerasi. Sebaran dan ukuran partikel dengan instrumen particle size analyzer (PSA) menunjukkan ukuran partikel berkisar antara 33-116 nm. Sampel NPAg-S pada dua konsentrasi (1 dan $2 \%$ ) menunjukkan adanya aktivitas penghambatan untuk semua jenis bakteri Gram positif dan Gram negatif. Hasil analisis distribusi ukuran partikel menggunakan PSA menunjukkan ukuran partikel sampel NPAg-S lebih kecil yaitu sebesar $33,8 \mathrm{~nm}$ dibandingkan sampel NPAg-K sebesar 44,8 nm. Aktivitas antibakteri sangat dipengaruhi oleh ukuran partikel dari suatu sampel. Ukuran nanopartikel perak yang kecil memiliki luas permukaan besar untuk berinteraksi dengan beberapa bakteri dibandingkan nanopartikel perak berukuran besar, sehingga dapat memberikan efek antibakteri lebih besar.
\end{abstract}

Kata kunci: aktivitas antibakteri, Jatropha curcas L., nanopartikel perak, particle size analyzer

\footnotetext{
*Penulis Korespondensi: E-mail: aranugrahayu@unmuhjember.ac.id
} 


\section{PENDAHULUAN}

Nanopartikel perak (NPAg) merupakan partikel logam perak yang memiliki ukuran kurang dari 100 $\mathrm{nm}$. NPAg memiliki keunggulan dibandingkan senyawa antimikroba atau antibiotik, yaitu memiliki aktivitas bakteriostatik yaitu dapat menghambat pertumbuhan mikroorganisme. Mekanisme antibakteri NPAg menurut Li et al. (2008) yaitu adanya adhesi nanopartikel terhadap permukaan bakteri yang mengubah sifat membran. Nanopartikel dengan ukuran kecil dan luas permukaan besar mampu berhubungan dengan permukaan mikroorganisme. NPAg terserap ke dalam membran sel bakteri melalui interaksi dengan fosfor ataupun senyawa mengandung sulfur yang menyebabkan perubahan strukur DNA sehingga menyebabkan kematian sel bakteri. NPAg melepaskan ion $\mathrm{Ag}^{+}$ yang dapat berinteraksi dengan protein yang mengandung sulfur dalam dinding sel bakteri. Ion $\mathrm{Ag}^{+}$terlarut berinteraksi dengan dinding sel dan protein sitoplasma. Potensi pengembangan NPAg di berbagai bidang sangat terbuka luas, antara lain sebagai marker (passive sensing agent) dan antimikroba. Pada bidang pangan, NPAg dapat diaplikasikan pada pengemas pangan sebagai film kemasan antimikroba. NPAg pada kemasan dapat memperpanjang daya tahan pangan. Bahan pangan dapat bertindak sebagai perantara atau substrat untuk pertumbuhan mikroorganisme patogenik, seperti beberapa jenis bakteri Gram positif dan Gram negatif sehingga perlu dilakukan upaya pencegahan perpindahan mikroba dari lingkungan ke bahan pangan dengan adanya film-coating berbahan NPAg.

Proses sintesis nanopartikel merupakan tahapan penting bagi pengembangan nanoteknologi. Pada umumnya, sintesis NPAg dilakukan menggunakan tiga metode, yaitu metode fisika, kimia, dan biologi. Metode fisika merupakan proses mereduksi padatan logam perak menjadi partikel perak berukuran nano secara mekanik serta membutuhkan peralatan yang mahal. Metode kimia dilakukan dengan cara menggunakan bahan kimia yang umumnya sangat reaktif dan beracun serta menjadi polutan bagi lingkungan maupun makhluk hidup. Metode reduksi dengan memanfaatkan ekstrak tumbuhan sebagai agen pereduksi bersifat aman dan mudah diperoleh sehingga dapat menjadi alternatif dalam preparasi nanopartikel (Renugadevi et al., 2012).

Sintesis NPAg dengan memanfaatkan ekstrak tumbuhan mampu mereduksi penggunaan bahan kimia berlebihan yang dapat menyebabkan pencemaran lingkungan. Menurut Nilavukkarasi et al. (2020), sintesis NPAg menggunakan ekstrak tumbuhan yang dapat berperan sebagai bioreduktor untuk menghasilkan nanopartikel perak merupakan metode sintesis yang sederhana, hemat biaya, ramah lingkungan, dan stabil. Contoh sintesis nanopartikel yang berhasil diperoleh dari ekstrak tumbuhan, baik dari intrasel maupun ekstrasel, antara lain ekstrak Ziziphora clinopodioides (Esmaile et al., 2020), ekstrak daun Capparis zeylanica L. (Nilavukkarasi et al., 2020), dan ekstrak daun dari tumbuhan M. balbisiana (banana), A. indica (neem), serta O. tenuiflorum (black tulsi) (Banerjee et al., 2014). Pada umumnya, senyawa fenolik pada ekstrak tanaman berperan penting sehingga memberi sifat antioksidan dan juga antibakteri (Esmaile et al., 2020). Senyawa seperti terpenoid, flavonoid, fenol, alkaloid, protein, dan karbohidrat dalam ekstrak dapat bertindak sebagai agen pereduksi nanopartikel perak yang ramah lingkungan (Alshehri et al., 2020). Sintesis nanopartikel dari sumber daya hayati dapat dilakukan pada senyawa yang memiliki kandungan alkaloid dan flavonoid. Penelitian ini bertujuan untuk sintesis nanopartikel perak (NPAg) dengan memanfaatkan ekstrak biji jarak pagar (Jatropha curcas L.) sebagai reduktor, dengan pengamatan pada aktivitas redoks secara spektrofotometrik, gugus aktif dengan FTIR, ukuran partikel dengan PSA, foto produk pada pembesaran 10.000 dan 15.000x dengan SEM, dan aktivitas antibakteri NPAg terhadap bakteri uji Gram positif (Staphylococcus aureus, Bacillus cereus) dan Gram negatif (Escherichia coli, Salmonella typhi). Pembanding yang digunakan dalam penelitian ini adalah NPAg komersial (Sigma Aldrich, USA).

\section{BAHAN DAN METODE}

\section{Bahan}

Penelitian ini menggunakan bahan utama, antara lain bubuk NPAg-K (Sigma Aldrich, USA) serta ekstrak biji jarak pagar (Jatropha curcas L.) dari Biosurfaktan yang digunakan sebagai agen pereduksi nanopartikel perak (NPAg). Uji aktivitas antimikroba menggunakan bahan, antara lain: media nutrient agar (NA) dan nutrient broth (NB) (Oxoid, Canada), serta beberapa jenis bakteri Gram negatif (Escherichia coli ATCC 25922 dan Salmonella typhi ATCC 14028) dan bakteri Gram positif (Staphylococcus aureus ATCC 25923 dan Bacillus cereus ATCC 10876) (Oxoid, Canada) dari Kultur Biakan Laboratorium Mikrobiologi, Fakultas Teknologi Pertanian, Institut Pertanian Bogor.

\section{Ekstraksi biji jarak}

Biji jarak dikeringkan terlebih dahulu pada suhu $60^{\circ} \mathrm{C}$ selama 12 jam. Setelah itu, biji jarak digiling kering menggunakan penggiling mekanik hingga diperoleh bubuk kering biji jarak. Sebanyak $50 \mathrm{~g}$ bubuk kering biji jarak direbus dengan menggunakan $1000 \mathrm{~mL}$ air deionisasi mendidih kemudian 
larutan direbus selama 2 jam (Martínez et al., 2019). Larutan biji jarak pagar dipisah antara fase cair dan fase padat menggunakan sentrifugasi kecepatan $10.000 \mathrm{rpm}$ selama 15 menit untuk menghilangkan residu yang tidak diinginkan. Kemudian dilakukan penyaringan dengan kertas Whatman No. 1 (Merck, Jerman). Hasil penyaringan cairan rebusan biji jarak pagar menjadi ekstrak biji jarak pagar (Jatropha curcas L.) digunakan untuk proses sintesis NPAg (Jagtap et al., 2013).

\section{Sintesis NPAg}

Sintesis dilakukan dengan mencampur larutan $\mathrm{AgNO}_{3}$ (Sigma Aldrich, Amerika) dan larutan ekstrak biji jarak pagar (Jatropha curcas L.). Larutan $\mathrm{AgNO}_{3}$ dengan konsentrasi $10^{-2} \mathrm{M}$ direaksikan dengan ekstrak biji jarak dengan perbandingan 1:5 (E1P5); 1:10 (E1P10); dan 1:15 (E1P15) (v:v) dan dilakukan pemanasan di atas penangas air listrik pada suhu $80^{\circ} \mathrm{C}$ (Martínez et al., 2019). Indikator telah terbentuknya nanopartikel perak, diamati dengan adanya perubahan warna larutan dari awalnya berwarna bening sampai berwarna kekuningan hingga cokelat setelah pemanasan selama 15 menit.

\section{Analisis spektrofotometri UV-Vis}

Hasil larutan NPAg diukur menggunakan spektrofotometer UV-Vis (UV-1800 Shimadzu, Jepang) yang memiliki resolusi $1 \mathrm{~nm}$. Instrumen spektrofotometer UV-Vis distandarisasi dengan menggunakan blanko. Blanko yang digunakan adalah air deionisasi. Panjang gelombang koloid perak pada kisaran 300-700 nm. Serapan di wilayah cahaya tampak adalah $370-500 \mathrm{~nm}$ dengan puncak plasmon berkisar pada $445 \mathrm{~nm}$ yang menunjukkan ciri khas nanopartikel perak (Sileikaite et al., 2006).

\section{Analisis particle size analyzer (PSA)}

Analisis distribusi ukuran nanopartikel perak diukur menggunakan particle size analyzer (PSA) (Horiba, SZ-100, Japan). Larutan yang mengandung nanopartikel perak dimasukkan ke dalam kuvet kemudian dianalisis dengan instrumen PSA (Balachandran, 2013). Pengukuran dilakukan pada suhu $25^{\circ} \mathrm{C}$ dengan indeks bias sebesar 1,3332 dan viskositas sampel sebesar $0,8878 \mathrm{cP}$.

\section{Analisis morfologi nanopartikel perak dengan scanning electron microscopy (SEM)}

Analisis ukuran dan bentuk nanopartikel perak menggunakan instrumen scanning electron microscopy (SEM) (JSM 5310 LV, JEOL, Jepang) dengan perbesaran 10.000 dan 15.000x. Prosedur analisisnya yaitu dengan meneteskan suspensi di atas plat listrik yang bersih dan memungkinkan air dapat menguap. Tegangan listrik yang digunakan untuk analisis menggunakan SEM yaitu sebesar $15 \mathrm{kV}$, serta sampel terlebih dahulu dilapisi dengan emas (Ibrahim, 2015).

\section{Analisis dengan fourier transform infra red (FTIR)}

Nanopartikel perak yang terbentuk dari ekstrak biji jarak pagar (Jatropha curcas L.) dipisahkan dari protein dan senyawa lain dengan cara diendapkan dengan teknik sentrifugasi pada kecepatan 10.000 rpm selama 20 menit. Hasil padatan yang diperoleh dikeringkan dengan menggunakan oven selama 24 jam. Kemudian diambil sebanyak $2 \mathrm{mg}$ sampel dicampur dengan $100 \mathrm{mg} \mathrm{KBr}$, dibuat pellet lalu di IR dengan jangakuan bilangan gelombang 4000$500 \mathrm{~cm}^{-1}$ menggunakan instrumen FTIR (ShimadzuFTIR spectrometer, Jepang) (Yadaf et al., 2018).

\section{Pengujian kapasitas antibakteri dari nanopartikel Ag (NPAg)}

Tahap pertama adalah persiapan kultur uji. Kultur murni bakteri yang diuji yaitu 2 macam bakteri Gram positif (Staphylococcus aureus, Bacillus cereus) dan Gram negatif (Escherichia coli, Salmonella typhi) diinokulasikan ke dalam $10 \mathrm{~mL}$ nutrient broth cair (NB) (Oxoid, Canada). Setelah itu, diinkubasi pada suhu $37^{\circ} \mathrm{C}$ selama 24 jam. Konsentrasi bakteri diatur hingga mencapai $10^{7} \mathrm{sel} / \mathrm{mL}$. Tahap kedua yaitu pengujian aktivitas antibakteri sebanyak $100 \mathrm{~mL}$ inokulum dimasukkan ke dalam cawan petri yang telah steril (diameter $6 \mathrm{~cm}$ ). Selanjutnya, ditambahkan $20 \mathrm{~mL}$ nutrient agar cair pada suhu $45^{\circ} \mathrm{C}$ sambil di homogenkan dan dibiarkan hingga menjadi padatan pada suhu $30^{\circ} \mathrm{C}$. Pada media yang telah padat diisi dengan NPAg yang telah disiapkan sebelumnya. Larutan NPAg-S kemudian diinkubasi pada suhu $37^{\circ} \mathrm{C}$ selama 24 jam. Daerah bening yang berada di sekitar sampel diukur diameternya (Balouiri et al., 2016).

\section{HASIL DAN PEMBAHASAN}

\section{Stabilitas nanopartikel perak}

Hasil ekstraksi biji jarak yang direaksikan dengan larutan $\mathrm{AgNO}_{3}$ memiliki rentang $\lambda_{\text {maks }}$ yang luas, yaitu berkisar antara 200 hingga $500 \mathrm{~nm}$. Pada Gambar 1 dapat terlihat bahwa larutan $\mathrm{AgNO}_{3}$ memiliki $\lambda_{\text {maks }}$ sebesar $200 \mathrm{~nm}$. Pada larutan ekstrak biji jarak, $\lambda_{\text {maks }}$ yang diperoleh lebih lebar, yaitu sebesar 250 hingga $300 \mathrm{~nm}$. Pada larutan ekstrak biji jarak yang direaksikan dengan larutan $\mathrm{AgNO}_{3}$, diperoleh kisaran $\lambda_{\text {maks }}$ yang berbeda yaitu antara 400 hingga $500 \mathrm{~nm}$. Menurut Solomon et al. (2007) dan Leela et al. (2008) NPAg memiliki absorpsi yang kuat pada panjang gelombang antara 400 hingga $500 \mathrm{~nm}$. Adanya serapan baru pada daerah 400-500 nm membuktikan bahwa proses sintesis NPAg 
menggunakan ekstrak biji jarak pagar (Jatropha curcas L.) telah berhasil terbentuk.

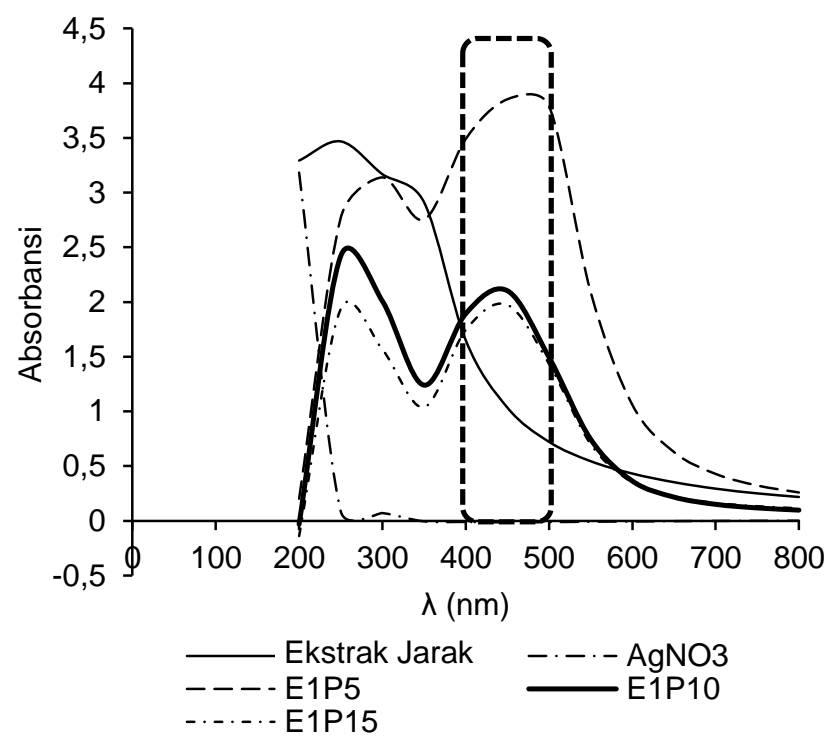

Gambar 1. Serapan NPAg pada rentang UV-Vis dengan variasi ekstrak jarak dan $\mathrm{AgNO}_{3}$

Berdasarkan hasil penelitian dengan mempelajari pengaruh variasi volume larutan $\mathrm{AgNO}_{3}$ yang direaksikan dengan larutan ekstrak biji jarak, diperoleh hasil bahwa $\lambda_{\text {maks }}$ terbesar terdapat pada variasi penambahan volume larutan $\mathrm{AgNO}_{3}$ yang paling sedikit yaitu sampel E1P5 (rasio volume ekstrak biji jarak: $\mathrm{AgNO}_{3}$ yaitu 1:5). Dapat dilihat pada Gambar 1 bahwa penurunan $\lambda_{\text {maks }}$ pada sampel E1P10 dan E1P15 terjadi seiring dengan meningkatnya volume larutan $\mathrm{AgNO}_{3}$ yang ditambahkan ke dalam larutan ekstrak biji jarak. Seperti penelitian terdahulu oleh Sari et al. (2017) yang memanfaatkan ekstrak buah kersen (Muntingia calabura L.) dan Taba et al. (2019) yang menggunakan ekstrak daun salam (Syzgium polyanthum) sebagai bioreduktor NPAg menunjukkan penurunan puncak serapan seiring semakin besarnya konsentrasi $\mathrm{AgNO}_{3}$ yang ditambahkan. Hal ini kemungkinan karena NPAg yang tersisa sangat sedikit akibat teroksidasinya NPAg menjadi ion $\mathrm{Ag}^{+}$sehingga tidak lagi memiliki kemampuan menyerap cahaya pada panjang gelombang optimum secara maksimal. Selain itu, terjadinya perubahan warna menjadi kuning kecokelatan hingga kemerahan menunjukkan kestabilan NPAg yang dihasilkan (Kasim et al., 2020).

\section{Senyawa fungsional nanopartikel perak}

Keberadaan senyawa fungsional yang terdapat pada larutan NPAg dapat dianalisis menggunakan instrumen fourier transform infra red (FTIR). Hasil FTIR pada Gambar 2, menunjukkan adanya puncak pada bilangan gelombang $3434,49 \mathrm{~cm}^{-1}$ yang meru- pakan karakteristik dari vibrasi peregangan $\mathrm{O}-\mathrm{H}$ yang menunjukkan adanya gugus hidroksil dalam zat pereduksi. Puncak serapan terlihat juga pada gelombang $2922,68 \mathrm{~cm}^{-1}$ dan $2853,65 \mathrm{~cm}^{-1}$ sesuai dengan peregangan ikatan $\mathrm{C}-\mathrm{H}$ aldehid. Ditemukan puncak lemah pada bilangan gelombang 1457,54 $\mathrm{cm}^{-1}$ dan $1383,68 \mathrm{~cm}^{-1}$ yang mengindikasikan terbentuknya vibrasi ikatan $\mathrm{C}-\mathrm{N}$ serta adanya gugus amida I dari protein dalam ekstrak biji jarak pagar (Jatropha curcas L.). Ikatan $\mathrm{C}=\mathrm{O}$ sebagai kelompok asam karboksilat ditunjukkan pada serapan bilangan gelombang $1736,14 \mathrm{~cm}^{-1}$. Puncak serapan ditemukan pada bilangan gelombang 1043,26 menunjukkan adanya vibrasi ikatan C-N pada kelompok gugus amina. Gugus amina yang terdapat dalam ekstrak biji jarak pagar (Jatropha curcas L.) memiliki peran dalam proses reduksi ion $\mathrm{Ag}^{+}$menjadi $\mathrm{Ag}^{\circ}$ (nanopartikel $\mathrm{Ag}$ ). Hasil ini menunjukkan bahwa protein dapat mengikat permukaan nanopartikel baik melalui kelompok amina bebas atau residu sistein yang bertindak sebagai agen penstabil nanopartikel perak. Serapan terendah terjadi pada bilangan gelombang 670,40 yang menunjukkan gugus $\mathrm{CH}$ dari senyawa etilen telah tersubtitusi menjadi ikatan $-\mathrm{CH}=\mathrm{CH}$ (cis). Adanya senyawa fungsional $\mathrm{C}=\mathrm{O}$ dan $\mathrm{O}-\mathrm{H}$ menunjukkan bahwa gugus-gugus ini berperan dalam dalam reaksi reduksi logam perak (Taba et al., 2019).

Adanya gugus fungsional yang ditunjukkan dalam analisis FTIR dapat memastikan bahwa ekstrak biji jarak pagar (Jatropha curcas L.) memiliki kemampuan ganda, baik sebagai agen pereduksi maupun penstabil NPAg (Umoren et al., 2014). Puncak bilangan gelombang serupa juga terjadi pada penelitian yang telah dilakukan oleh Devaraj et al. (2013) yang melakukan sintesis dan karakterisasi NPAg menggunakan daun Cannonball menemukan adanya perbedaan satu gugus fungsional yaitu gugus fitokonstituen dalam ekstrak daun Cannonball yang memengaruhi bentuk dan stabilitas dari NPAg yang dihasilkan. Ekstrak daun yang mengandung senyawa polifenol sangat tinggi juga memiliki peran utama dalam membentuk NPAg yang stabil. Gugus karboksil dan gugus amina berperan penting dalam proses reduksi dan membentuk kestabilan dari NPAg (Muzamil et al., 2014).

\section{Morfologi permukaan nanopartikel perak (NPAg)}

Morfologi NPAg dari ekstrak biji jarak dapat dianalisis salah satunya menggunakan instrumen scanning electron microscopy (SEM) pada perbesaran 10.000 dan 15.000x. Berdasarkan data yang telah diperoleh pada Gambar 3 dapat dilihat bahwa morfologi sebaran NPAg dalam larutan ekstrak biji jarak bersifat polidispersi dan berbentuk bola berserabut dengan partikel yang tidak seragam serta cenderung beraglomerasi. 


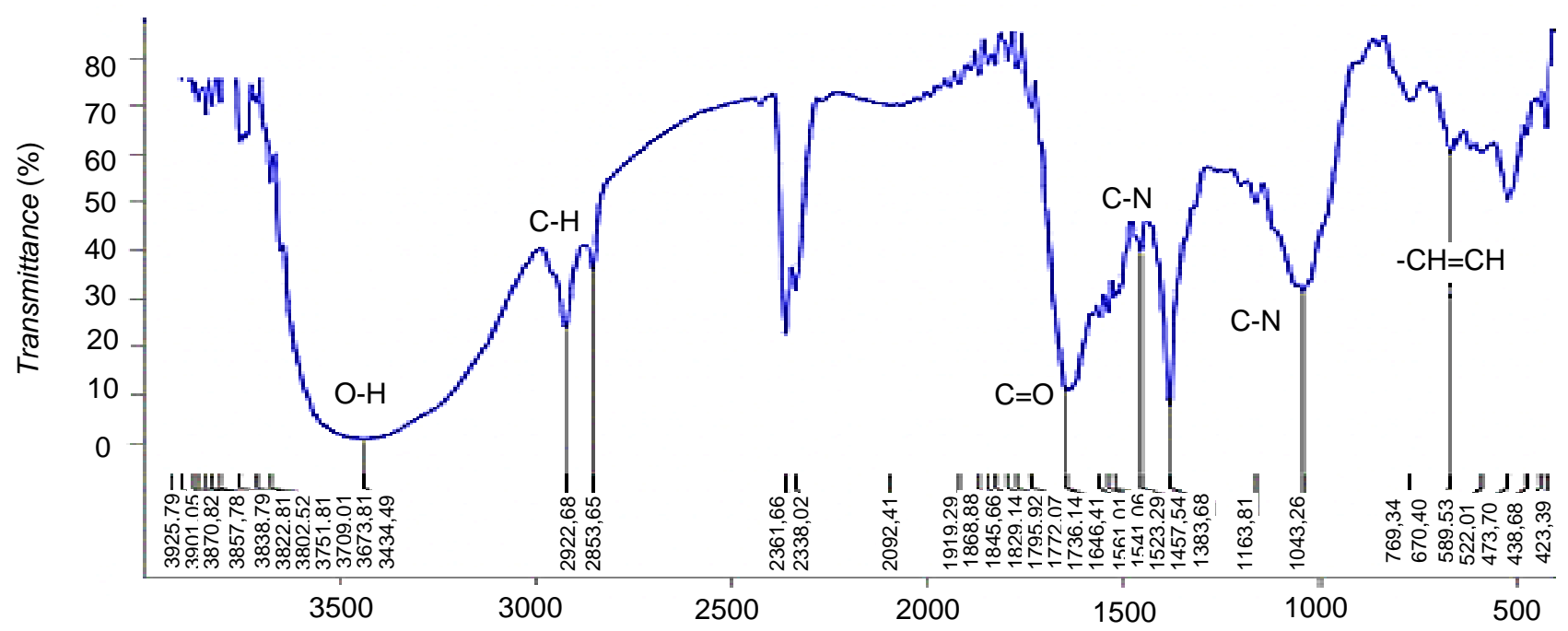

Wavenumber $\mathrm{cm}^{-1}$

Gambar 2. Spektrogram FTIR dari NPAg yang diproduksi dari kombinasi ekstrak biji jarak dan $\mathrm{AgNO}_{3}(1: 5)$

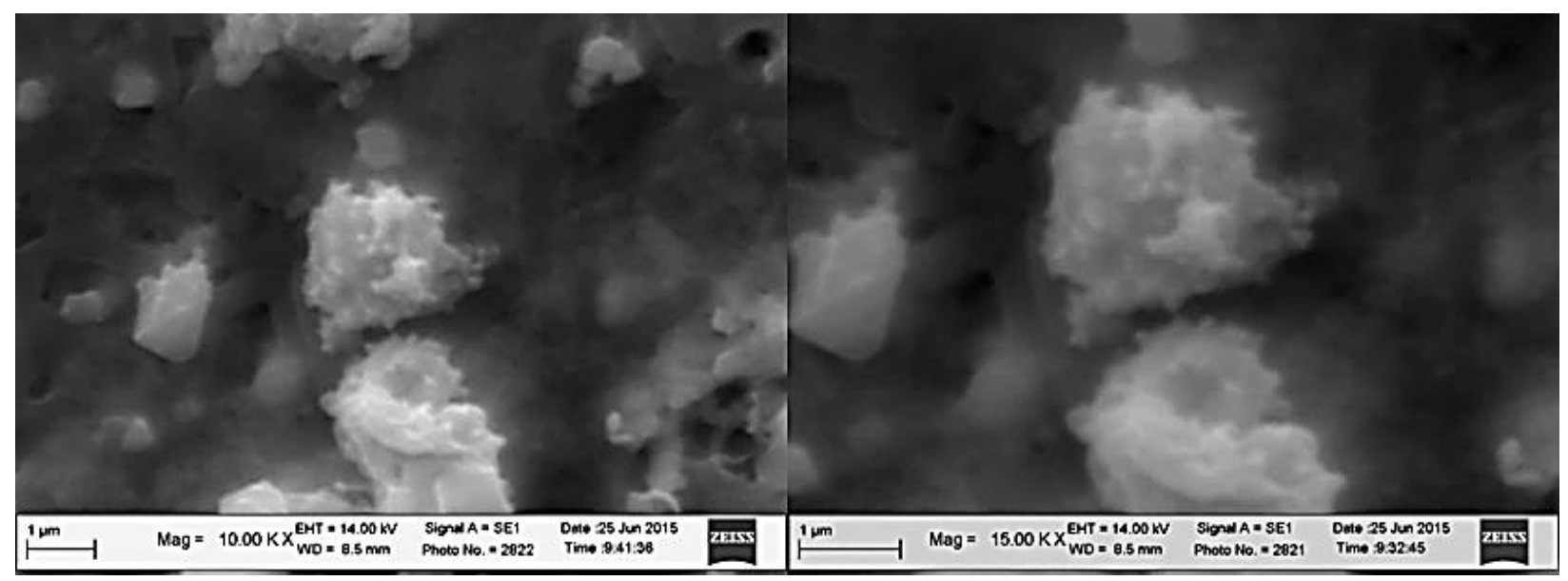

A

B

Gambar 3. Hasil SEM pada NPAg-S perbesaran 10000x (A) dan 15000x (B)

Sama halnya dengan penelitian Masakke et al. (2014) dengan menggunakan ekstrak daun manggis mendapatkan NPAg dengan ukuran yang bervariasi dan tidak seragam akibat adanya agregasi. Bentuk dan ukuran NPAg berperan penting dalam menentukan sifat nanopartikel seperti sifat optik, mekanik, konduktif, dan toksisitas. Kecenderungan NPAg beragregasi disebabkan adanya efek gerak Brown dan gaya Van der Waals dalam larutan. Adanya kecenderungan NPAg untuk beragregasi menyebabkan ukuran atau diameter partikel nano tidak seragam. Terjadinya agregasi NPAg tersebut dapat diamati dari hasil analisis PSA yang menunjukkan ukuran nanopartikel bervariasi dari 33,8-116,3 nm. Beberapa penelitian yang telah dilakukan Firdhouse et al. (2012) dengan melakukan sintesis NPAg menggunakan ekstrak etanol daun wijaya kusuma (Pisonia grandis) yang direaksikan dengan $3 \mathrm{mM}$ $\mathrm{AgNO}_{3}$ pada suhu $90^{\circ} \mathrm{C}$ dan Mason et al. (2012) yang mensintesis NPAg menggunakan ekstrak Panicum virgatum yang direaksikan dengan $3 \mathrm{mM}$ $\mathrm{AgNO}_{3}$ pada suhu kamar juga diperoleh NPAg yang memiliki partikel berbentuk bola dengan perkiraan ukuran yang didapat antara 20-150 nm.

\section{Ukuran partikel}

Pada Gambar 4 ditunjukan distribusi ukuran partikel untk sampel E1P5, E1P10, dan E1P15. Hasil pengukuran PSA berbentuk distribusi sehingga dapat digunakan untuk menentukan ukuran partikel 
secara keseluruhan. Indeks bias dan viskositas penting diketahui untuk meningkatkan akurasi pengukuran menggunakan instrumen PSA.

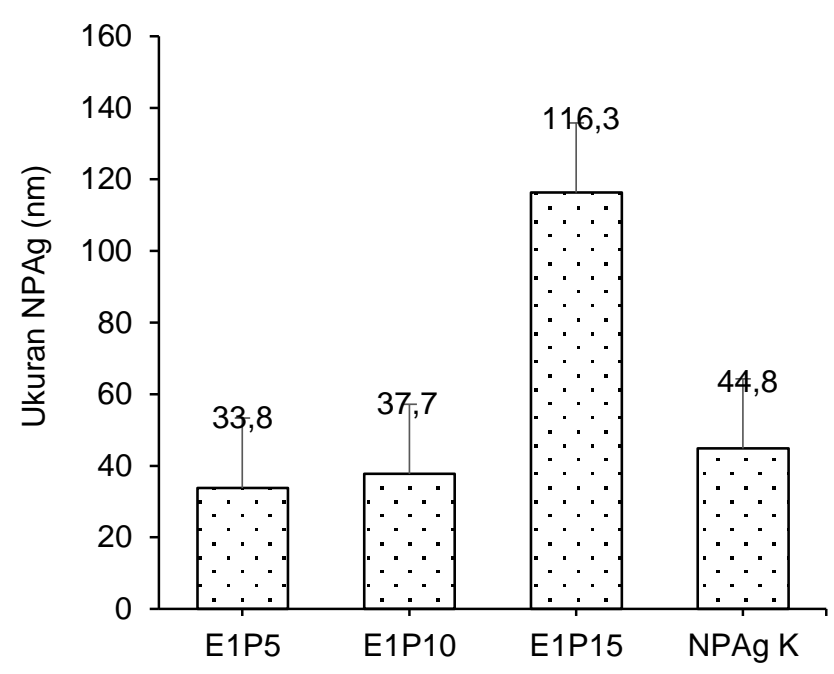

Perbandingan Larutan AgNO dengan Ekstrak Biji Jarak

Gambar 4. Distribusi ukuran nanopartikel perak pada sampel

Berdasarkan data ukuran partikel (Gambar 4) dapat dilihat bahwa formulasi sampel E1P5 menghasilkan ukuran partikel rerata yang paling kecil dibanding sampel E1P10 dan E1P15. Formulasi sampel E1P5 memiliki ukuran NPAg sebesar 33,8 nm. Sampel E1P10 dan E1P15 memiliki ukuran NPAg yang terbentuk semakin besar yaitu sebesar $37,7 \mathrm{~nm}$ hingga 116,3 nm. Seperti penelitian Ahmed et al. (2016) yang telah berhasil mendapatkan ukuran NPAg sebesar $34 \mathrm{~nm}$ dari hasil sintesis ekstrak daun Azadirachta indica dengan NPAg pada suhu ruang. Begitu juga dengan ukuran NPAg yang didapatkan oleh Jyoti et al. (2016) yang berhasil sintesis NPAg dari ekstrak daun Urtica dioica Linn menghasilkan NPAg berukuran $36 \mathrm{~nm}$ pada suhu $40^{\circ} \mathrm{C}$. Semakin besar konsentrasi $\mathrm{AgNO}_{3}$ yang digunakan dalam sintesis menyebabkan semakin banyak jumlah $\mathrm{Ag}^{+}$yang harus direduksi sehingga terjadi aglomerasi lebih besar dan mengakibatkan distribusi ukuran NPAg menjadi semakin besar. Menurut Guzmán (2009) menyatakan bahwa ukuran partikel perak berpengaruh terhadap aktivitas antibakteri, semakin kecil ukuran nanopartikel perak semakin besar efek antibakterinya.

\section{Hasil pengujian aktivitas antibakteri}

Aktivitas antibakteri menggunakan dua jenis bakteri, yaitu bakteri Gram positif (Staphylococcus aureus dan Bacillus cereus) dan Gram negatif (Escherichia coli dan Salmonella typhi). Penga- matan antibakteri dilakukan pada sampel NPAg-S (nanopartikel perak hasil sintesis) dan NPAg-K (nanopartikel perak produk komersil) dengan variasi dua perlakuan konsentrasi yang berbeda yaitu 1 dan $2 \%$ (Gambar 5). Berdasarkan hasil pengujian aktivitas antibakteri yang dapat dilihat pada Gambar 6 , sampel NPAg-K dengan konsentrasi sebesar 1\% tidak ditemukan adanya daya hambat untuk semua jenis bakteri Gram positif dan Gram negatif. Aktivitas penghambatan baru terlihat pada sampel NPAg-K dengan peningkatan konsentrasi sebesar $2 \%$. Nilai diameter hambat tertinggi terdapat pada bakteri Bacillus cereus yaitu sebesar $7,80 \mathrm{~mm}$. Lain halnya dengan sampel NPAg-S pada dua konsentrasi (1 dan $2 \%$ ) yang menunjukkan adanya aktivitas penghambatan untuk semua jenis bakteri Gram positif dan Gram negatif. Diameter penghambatan optimum terjadi pada bakteri Escherichia coli pada kedua konsentrasi 1 dan $2 \%$ berturut-turut sebesar 10,59 dan 11,11 mm.

Beberapa studi telah dilakukan dalam melihat aktivitas antibakteri NPAg dari sintesis ekstrak daun pecan (Carya illinoinensis) oleh Dalir et al. (2020) pada bakteri Gram positif (Staphylococcus aureus dan Listeria monocytogenes) dan bakteri Gram negatif (Escherichia coli dan Pseudomonas aeruginosa) menyatakan adanya kemungkinan NPAg menempel pada permukaan membran sel bakteri yang dapat mengganggu permeabilitas sel bakteri, menembus kedalam sel bakteri, dan memengaruhi permeabilitas dan respirasi membran sel. Membran sel bakteri mengandung protein dengan komponen utamanya yaitu sulfur. Protein inilah yang berinteraksi dengan NPAg dan kemudian berinteraksi lagi dengan fosfor yang mengandung senyawa seperti DNA yang menyebabkan kerusakan hingga memberikan efek mematikan terhadap mikroorganisme (Rao et al., 2017).

Hasil pengujian aktivitas antibakteri menunjukkan bahwa sampel NPAg-S lebih efektif dibandingkan NPAg-K dalam penghambatan bakteri baik Gram positif dan Gram negatif. Hasil analisis distribusi ukuran partikel menggunakan PSA diperoleh ukuran partikel sampel NPAg-S lebih kecil yaitu sebesar 33,8 nm dibandingkan sampel NPAg-K sebesar 44,8 nm. Aktivitas antibakteri sangat dipengaruhi oleh ukuran partikel dari suatu sampel. Hal ini seperti yang telah dijelaskan oleh Yadav et al. (2018) bahwa ukuran nanopartikel perak yang kecil memiliki luas permukaan besar untuk berinteraksi dengan beberapa bakteri dibandingkan nanopartikel perak berukuran besar, sehingga dapat memberikan efek antibakteri lebih besar. Peningkatan ukuran partikel akan mengurangi luas permukaan yang kontak dengan bakteri dan mengurangi tingkat eliminasi bakteri (Pal et al., 2007). 


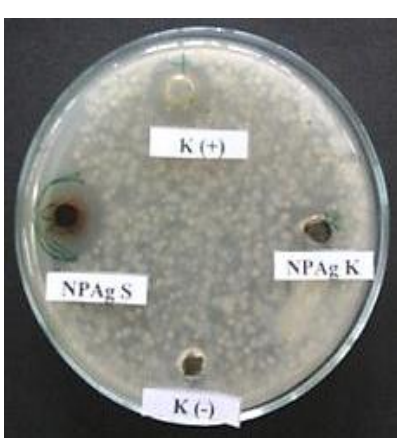

B. ceureus

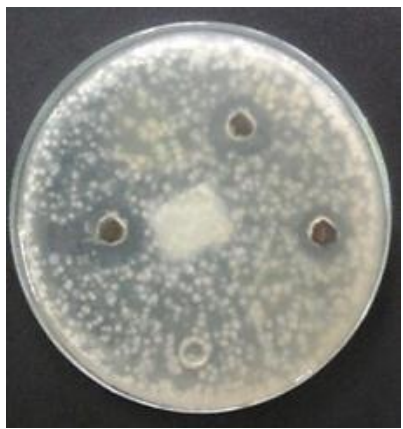

B. ceureus

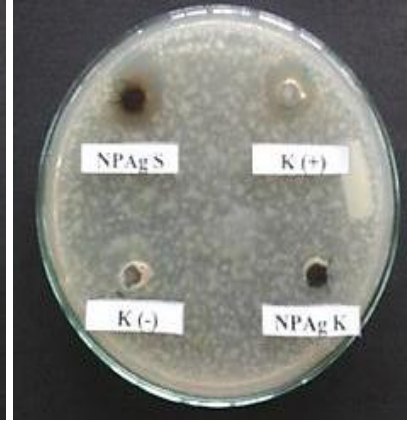

E. coli

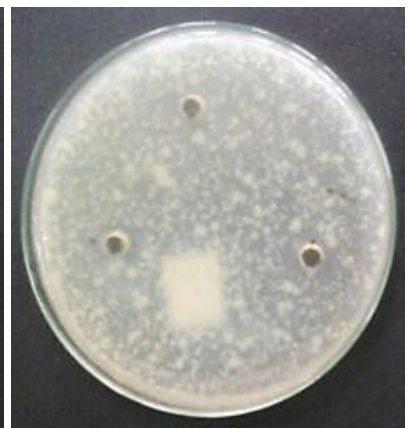

E. coli

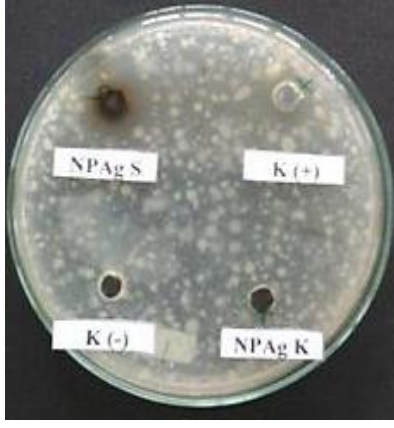

S.aureus

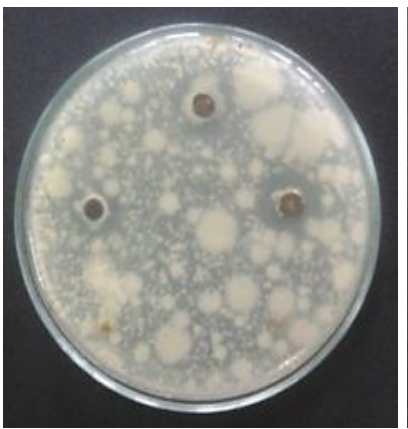

S.aureus

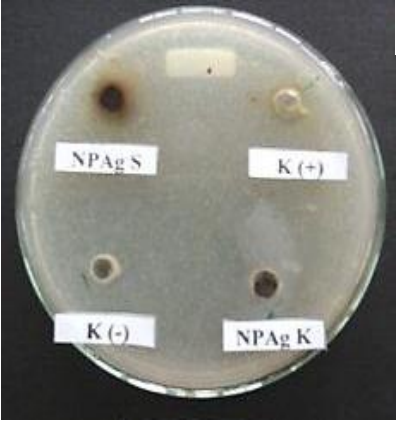

Salmonella typhi

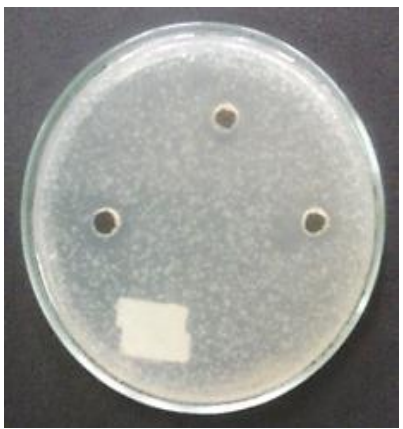

Salmonella typhi

Gambar 5. Visualisasi antibakteri untuk dua sampel (NPAg-S dan NPAg-K) pada konsentrasi $1 \%(\mathrm{~A})$ dan konsentrasi $2 \%(B)$

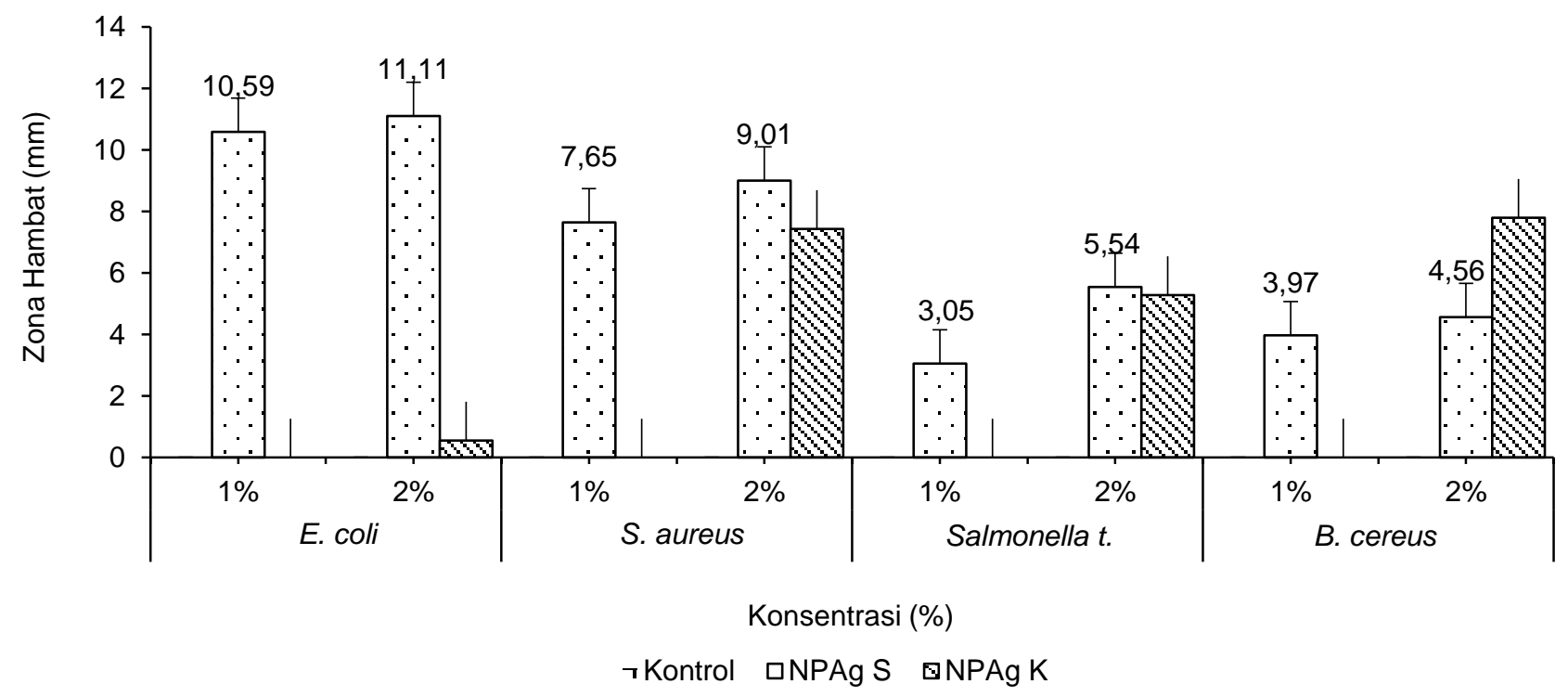

Gambar 6. Grafik uji aktivitas antibakteri untuk sampel nanopartikel perak (NPAg)

\section{KESIMPULAN}

Sintesis nanopartikel perak menggunakan $\mathrm{AgNO}_{3}$ dan ekstrak biji jarak pagar (Jatropha curcas L.) sebagai agen pereduksi telah berhasil dilakukan dengan memperoleh ukuran partikel antara 33 hingga $116 \mathrm{~nm}$. Ketidakstabilan ukuran NPAg memerlukan perlakuan sonikasi dan penambahan stabilisator sehingga diperoleh ukuran partikel yang stabil dan bentuk seragam. Adanya gugus karboksil dan gugus amina berperan penting dalam proses reduksi serta membentuk kestabilan dari NPAg yang 
dihasilkan. Larutan NPAg hasil sintesis memiliki kemampuan sebagai antimikroba. NPAg-S lebih efektif dalam menghambat bakteri Gram negatif (Escherichia coli) pada variasi pemberian konsentrasi nanopartikel perak 1 dan $2 \%$. Morfologi sebaran NPAg dalam larutan ekstrak biji jarak bersifat polidispersi dan berbentuk bola berserabut dengan partikel yang tidak seragam serta cenderung beraglomerasi.

\section{DAFTAR PUSTAKA}

Ahmed S, Saifullah, Ahmad M, Swami BL, Ikram S. 2016. Green synthesis of silver nanoparticles using Azadirachta indica aqueous leaf extract. J Radiat Res and Appl Sci 9: 1-7. DOI: 10.1016/j. jrras.2015.06.006.

Alshehri MA, Aziz AT, Trivedi S, Alanazi NA, Panneerselvam C, Baeshen R, Alatawi A. 2020. One-Step Synthesis of $\mathrm{Ag}$ nanoparticles using aqueous extracts from sundarbans mangroves revealed high toxicity on major mosquito vectors and microbial pathogens. J Cluster Sci 31: 177-84. DOI: 10.1007/s10876-019-01631-7.

Balachandran YL, Girijia S, Selvakumar R, Tongpim S, Cutleb AC, Arno CG, Suriyanarayanan S. 2013. Differently environment stable bio-silver nanoparticles: Study on their optical enhancing and antibacterial properties. Plos One 8: e77046. DOI: 10.1371/journal.pone.0077043.

Balouiri M, Sadiki M, Ibnsouda SK. 2016. Methods for in vitro evaluating antimicrobial activity - a review. J Pharm Anal 6: 71-79. DOI: 10.1016/j. jpha.2015.11.005.

Banerjee P, Satapathy M, Mukhopahayay, Das P. 2014. Leaf extract mediated green synthesis of silver nanoparticles from widely available Indian plants: synthesis, characterization, antimicrobial property and toxicity analysis. Bioresource Bioproc 1: 1-10. DOI: 10.1186/s40643-0140003-y.

Dalir SJB, Djahaniani H, Nabati F, Hekmati M. 2020. Characterization and the evaluation of antimicrobial activities of silver nanoparticles biosynthesized from Carya illinoinensis leaf extract. Heliyon 6: 1-7. DOI: 10.1016/j.heliyon. 2020.e03624.

Devaraj P, Kumari P, Aarti C, Rengnathan A. 2013. Synthesis and characterization of silver nanoparticles using Cannonball leaves and their cytotoxic activity againts MCF-7 cell line. J
Nanotechnol 2013: 1-5. DOI: 10.1155/2013/598 328.

Esmaile F, Hassan K, Hassan AP. 2020. Characterization and antibacterial activity of silver nanoparticles green synthesized using Ziziphora clinopodioides extract. Environ Nanotechnol, Monitoring Manage 14: 100303. DOI: 10.1016/j. enmm.2020.100303.

Firdhouse MJ, Ramadas LP, Shubashini S. 2012. Novel synthesis of silver nanoparticles using leaf ethanol extract of Pisoniagrandis ( $\mathrm{R}$. $\mathrm{Br})$. Der Pharma Chemica 4: 2320-2326.

Guzmán MG, Dille J, Godet S. 2009. Synthesis of silver nanoparticles by chemical reduction method and their antibacterial activity. Int $\mathrm{J}$ Chem Biomol Eng 2: 104-111.

Ibrahim HMM. 2015. Green synthesis and characterization of silver nanoparticles using banana peel extract and their antimicrobial activity against representative microorganisms. J Radiat Res Appl Sci 8: 265-275. DOI: 10.1016/j. jrras.2015.01.007.

Jagtap UB, Bapat VA. 2013. Green synthesis of silver nanoparticles using Artocarpus heterophyllus Lam. seed extract and its antibacterial activity. Ind Crop Prod 46: 132-137. DOI: 10. 1016/j.indcrop.2013.01.019.

Jyoti K, Baunthiyal M, Singh A. 2016. Characterization of silver nanoparticles synthesized using Urtica dioica Linn. leaves and their synergistic effect with antibiotics. J Radiat Res Appl Sci 9: 217-227. DOI: 10.1016/j.jras.2015.10.002.

Kasim S, Taba P, Ruslan, Rumianto. 2020. Sinte-sis nanopartikel perak menggunakan ekstrak daun eceng gondok (Eichornia crassipes) seba-gai bioreduktor. Kovalen: J Riset Kimia 6: 126-133. DOI: 10.22487/kovalen.2020.v6.i2.15137.

Leela A, Vivekanandan M. 2008. Tapping the unexploited plant resources for the synthesis of silver nanoparticles. Afr J Biotechnol 7: 31623165.

Li Q, Mahendra S, Lyon DY, Brunet L, Liga MV, Li D, Alvares PJJ. 2008. Antimicrobial nanomaterials for water disinfection and microbial control: Potential applications and implications. Water Res 42: 4591-4602. DOI: 10.1016/j. watres.2008.08.015.

Martínez A, Mijangos GE, Romero-lbarra IC, Hernández-Altamirano R HA, Mena-Cervantes VY. 2019. In-situ transesterification of Jatropha curcas $L$. seeds using homogeneous and heterogeneous basic catalysts. Fuel 235: 277-287. DOI: 10.1016/j.fuel.2018.07.082. 
Mason C, Vivekanandhan S, Misra M, Mohanty AK. 2012. Switchgrass (Panicum virgatum) extract mediated green synthesis of silver nanoparticles. World J Nano Sci Eng 2: 47-52. DOI: 10.4236/wjnse.2012.22008.

Masakke Y, Sulfikar, Rasyid M. 2014. Biosintesis partikel-nano perak menggunakan ekstrak metanol daun manggis (Garcinia mangostana L.). J Sainsmat 4: 28-41.

Muzamil M, Khalid N, Aziz MD, Abbas SA. 2014. Synthesis of silver nanoparticles by silver salt reduction and its characterization. IOP Conference Series Mater Sci Eng 60: 012034. International Symposium on Advanced Materials (ISAM 2013) 23-27 September 2013, Islamabad, Pakistan. DOI: 10.1088/1757-899X/ 60/1/012034.

Nilavukkarasi M, Vijayakumar S, Kumar SP. 2020. Biological synthesis and characterization of silver nanoparticles with Capparis zeylanica L. leaf extract for potent antimicrobial and anti proliferation efficiency. Mater Sci for Energ Technol 3: 371-376. DOI: 10.1016/j.mset.2020. 02.008 .

Pal S, Tak YK, Song JM. 2007. Does the antibacterial activity of silver nanoparticles depend on the shape of the nanoparticle? A study of the Gram-Negative bacterium Escherichia coli. Appl Environ Microbiol 73: 17121720. DOI: 10.1128/AEM.02218-06.

Rao B, Tang R-C. 2017. Green synthesis of silver nanoparticles with antibacterial activities using aqueous Eriobotrya japonica leaf extract. Adv Nat Sci: Nanosci Nanotechnol 8: 1-8. DOI: 10.1088/2043-6254/aa5983.
Renugadevi K, Aswini RV. 2012. Microwave irradiation assisted synthesis of silver nanoparticle using Azadirachta indica leaf extract as a reducing agent and in vitro evaluation of its antibacterial and anticancer activity. Int $\mathrm{J}$ Nanomater Biostructure 2: 5-10.

Sari PI, Firdaus ML, Elvia R. 2017. Pembuatan nanopartikel perak (NPP) dengan bioreduktor ekstrak buah Muntingia calabura L untuk analisis logam merkuri. J Pendidikan IImu Kimia 1: 20-26. DOI: 10.33369/atp.v1i1.2708.

Šileikaitè A, Prosyčevas I, Puišo J, Juraitis A, Guobienè A. 2006. Analysis of silver nanoparticles produced by chemical reduction of silver salt solution. Mater Sci 12: 287-291.

Solomon SD, Bahadory $M$, Jeyarajasingam AV, Rutkowsky SA, Boritz C, L Mulfinger L. 2007. Synthesis and study of silver nanoparticles. J Chem Educ 84: 322-325. DOI: 10.1021/ed084p 322.

Taba P, Parmitha NY, Kasim S. 2019. Sintesis nanopartikel perak menggunakan ekstrak daun salam (Syzgium polyanthum) sebagai bioreduktor dan uji aktivitasnya sebagai antioksidan. Indonesian J Chem Res 7: 51-60. DOI: 10.3059 8//ijcr.2019.7-ptb.

Umoren SA, Obot IB, Gasem ZM. 2014. Green synthesis and characterization of silver nanoparticles using red apple (Malus domestica) fruit extract at room temperature. J Mater Environ Sci 5: 907-914.

Yadav A, Kaushik A, Joshi A. 2018. Green synthesis of silver nanoparticles using Ocimum sanctum $\mathrm{L}$. and Ocimum americanum $\mathrm{L}$. for their antibacterial potential. Int J Life Sci Pharm Res 8: 42-49. 